\title{
Exploring Kinase Inhibition Properties of 9H-pyrimido[5,4-b]- and [4,5-b]indol-4-amine Derivatives
}

\author{
Yvonnick Loidreau ${ }^{1}$, Carole Dubouilh-Benard ${ }^{1}$, Marie-Renée Nourrisson ${ }^{2}$, Nadège Loaëc ${ }^{3}$, \\ Laurent Meijer ${ }^{3,4}$, Thierry Besson ${ }^{1, * \mathbb{D}}$ and Pascal Marchand ${ }^{2, * \mathbb{D}}$ \\ 1 Normandie Université, UNIROUEN, INSA Rouen, CNRS, COBRA UMR 6014, F-76000 Rouen, France; \\ yvonnick.loidreau@gmail.com (Y.L.); carole.dubouilh@univ-rouen.fr (C.D.-B.) \\ 2 Université de Nantes, Cibles et Médicaments des Infections et du Cancer, IICiMed, EA 1155, \\ F-44000 Nantes, France; marie-renee.nourrisson@univ-nantes.fr \\ 3 Station Biologique de Roscoff, Protein Phosphorylation \& Human Disease Group, 29680 Roscoff, France; \\ nadege.loaec@univ-brest.fr (N.L.); meijer@perha-pharma.com (L.M.) \\ 4 Perha Pharmaceuticals, Perharidy Peninsula, 29680 Roscoff, France \\ * Correspondence: thierry.besson@univ-rouen.fr (T.B.); pascal.marchand@univ-nantes.fr (P.M.); \\ Tel.: +33-235-522-904 (T.B.); +33-253-009-155 (P.M.)
}

Received: 10 April 2020; Accepted: 8 May 2020; Published: 9 May 2020

check for updates

\begin{abstract}
We previously highlighted the interest in 6,5,6-fused tricyclic analogues of 4-aminoquinazolines as kinase inhibitors in the micromolar to the nanomolar range of $\mathrm{IC}_{50}$ values. For the generation of chemical libraries, the formamide-mediated cyclization of the cyanoamidine precursors was carried out under microwave irradiation in an eco-friendly approach. In order to explore more in-depth the pharmacological interest in such tricyclic skeletons, the central five member ring, i.e., thiophène or furan, was replaced by a pyrrole to afford $9 H$-pyrimido[5,4-b]- and [4,5-b]indol-4-amine derivatives inspired from harmine. The inhibitory potency of the final products was determined against four protein kinases $(\mathrm{CDK} 5 / \mathrm{p} 25, \mathrm{CK} 1 \delta / \varepsilon, \mathrm{GSK} 3 \alpha / \beta$, and DYRK1A). As a result, we have identified promising compounds targeting $C K 1 \delta / \varepsilon$ and DYRK1A and displaying micromolar and submicromolar $\mathrm{IC}_{50}$ values.
\end{abstract}

Keywords: microwave-assisted chemistry; protein kinases; CK1; DYRK1A; CDK5; GSK-3

\section{Introduction}

Protein kinases are an important family of enzymes able to phosphorylate tyrosine (Tyr) and serine (Ser)/threonine (Thr) residues present in various proteins [1]. Abnormal protein kinase regulation and phosphorylation are now associated with numerous diseases including cancer [2,3], and neurodegenerative disorders [4-6]. In the last decade, about 300 protein kinase inhibitors were involved in clinical trials and 49 have been recently approved by the US Food and Drug Administration (FDA), mostly tyrosine kinase inhibitors, and mainly for cancer therapy [7]. In the same period, our groups have been particularly invested in the development of efficient and eco-compatible chemical methodologies allowing rapid access to libraries of potent bioactive arenes and their heteroarenes analogues. Studying ancestral thermal-sensitive reactions for which usual methods require forcing conditions or prolonged reaction times (e.g., Niementowski reaction [8,9] and Dimroth transposition [10]), microwave-assisted syntheses of novel benzo[b]thieno[3,2- $d$ ]pyrimidin-4-amines (series A) [11,12] and their pyrido (series B) and pyrazino analogues (series C) [13,14] have been successfully described (Figure 1). In this context, more than one hundred derivatives of the heterocyclic systems have been studied. Among them, the pyrido $[b]$ thieno[3,2- $d]$ pyrimidin-4-amine derivatives 
(series B) have shown the most interesting selectivity and inhibitory potency towards CK $1 \delta / \varepsilon$ over the other tested enzymes (CDK5/p25, GSK3 $\alpha / \beta$, and Dyrk1A) [14].
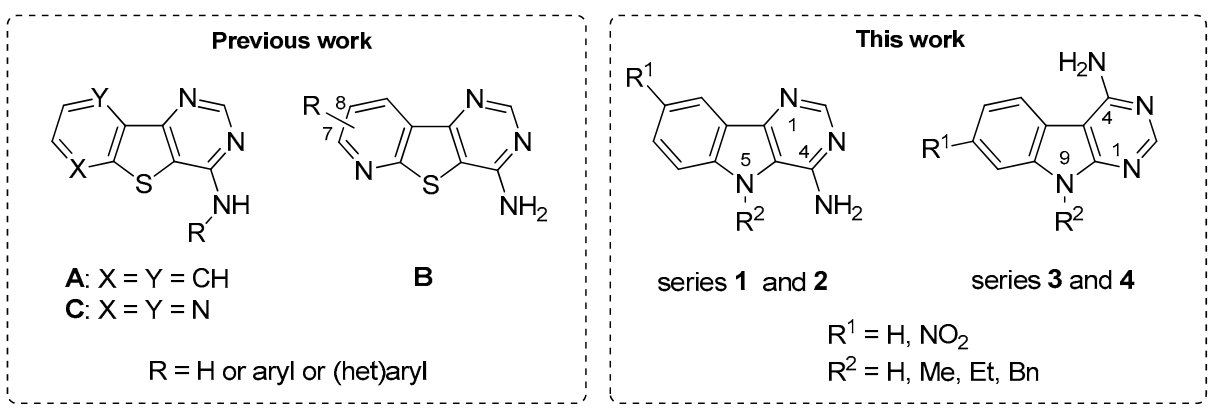

Figure 1. Previous benzo[b]thieno[3,2- $d]$ pyrimidin-4-amines (A) and their pyrido (B) and pyrazino (C) analogues (left). The $9 H$-pyrimido[5,4- $b$ ] indol-4-amine derivatives (1 and 2) and their $9 H$ pyrimido[4,5- $b$ ] indole isomers (3 and 4 ) described in this work (right).

In an effort to expand the chemical space and to highlight efficient kinase inhibitors, the synthesis of indole counterparts of the previously-described series has been envisaged. Such compounds are considered as analogues of harmine (see 11a in Scheme 2), a natural alkaloid that still generates a lot of work in the hope of developing therapies for Alzheimer's disease (AD) and Down syndrome (DS) $[15,16]$. This paper describes simple and convenient synthetic routes to $9 H$-pyrimido[5,4- $b$ ]indol-4-amine derivatives (series 1 and 2) and their 9Hpyrimido[4,5-b]indole isomers (series 3 and 4). The chemistry described in this paper was mainly carried out under microwave irradiation in an eco-friendly approach. Kinase inhibition of the products obtained was evaluated on an array of four Ser/Thr kinases (CDK5/p25, CK1 $/ \delta$, DYRK1A, and GSK3 $\alpha / \beta)$, all members of the CMGC kinase family, chosen for their strong implication in various cellular regulation processes [17-25].

\section{Results}

\subsection{Chemistry}

Synthesis of series 1, 2, 3, and 4 was inspired from our previous works on various benzo-, pyrido-, and pyrazino[b]thieno[3,2-d] pyrimidines (see series A, B and C in Figure 1) [11-14]. The nitrogen ring in pyridine and in pyrazine may be considered to be deactivated compared with benzene. It is sometimes compared with nitrobenzene as the molecules behave similarly in relation to the deficit of electron density. This consideration guided the choice of the nitro substitution $\left(\mathrm{R}^{1}\right)$ on the starting indole derivatives for completion of the structure-activity relationship (SAR) study. The $N^{\prime}$-(cyano-1H-indolyl)- $N, N$-dimethyl formimidamide precursors $(\mathbf{7 a}-\mathbf{d}, \mathbf{8 a}-\mathbf{d}, \mathbf{9 a}-\mathbf{d}$, and $\mathbf{1 0 a}-\mathbf{d})$ were heated at $170-200{ }^{\circ} \mathrm{C}$ under microwaves in the presence of an excess of formamide (40 equiv.) (for reaction times and yields see Table 1 ).

Functionalized indoles $(7 \mathbf{a}-\mathbf{d}, \mathbf{8 a}-\mathbf{d}, \mathbf{9 a}-\mathbf{d}$, and $\mathbf{1 0 a}-\mathbf{d})$ were previously obtained from 3-amino- $1 H$-indole-2-carbonitriles $(\mathbf{5 a}, \mathbf{b})$ or their 5-nitro-3-amino- $1 H$-indole-2-carbonitrile isomers $(\mathbf{6 a}, \mathbf{b})$ which were condensed with 10 equiv. of DMF-dialkylacetals like $N, N$-dimethylformamide dimethyl acetal (DMF-DMA), N,N-dimethylformamide diethyl acetal (DMF-DEA), and N,N-dimethylformamide dibenzyl acetal (DMF-DBA), respectively (Scheme 1). A strict control of the experimental conditions in terms of temperature and reaction time allowed access to the expected compounds in good to excellent yields (for details on suggested mechanism and experimental details see ref. [26]). 
Table 1. Synthesis of series 1, 2, 3, and 4: temperature, reaction time, and isolated yields.

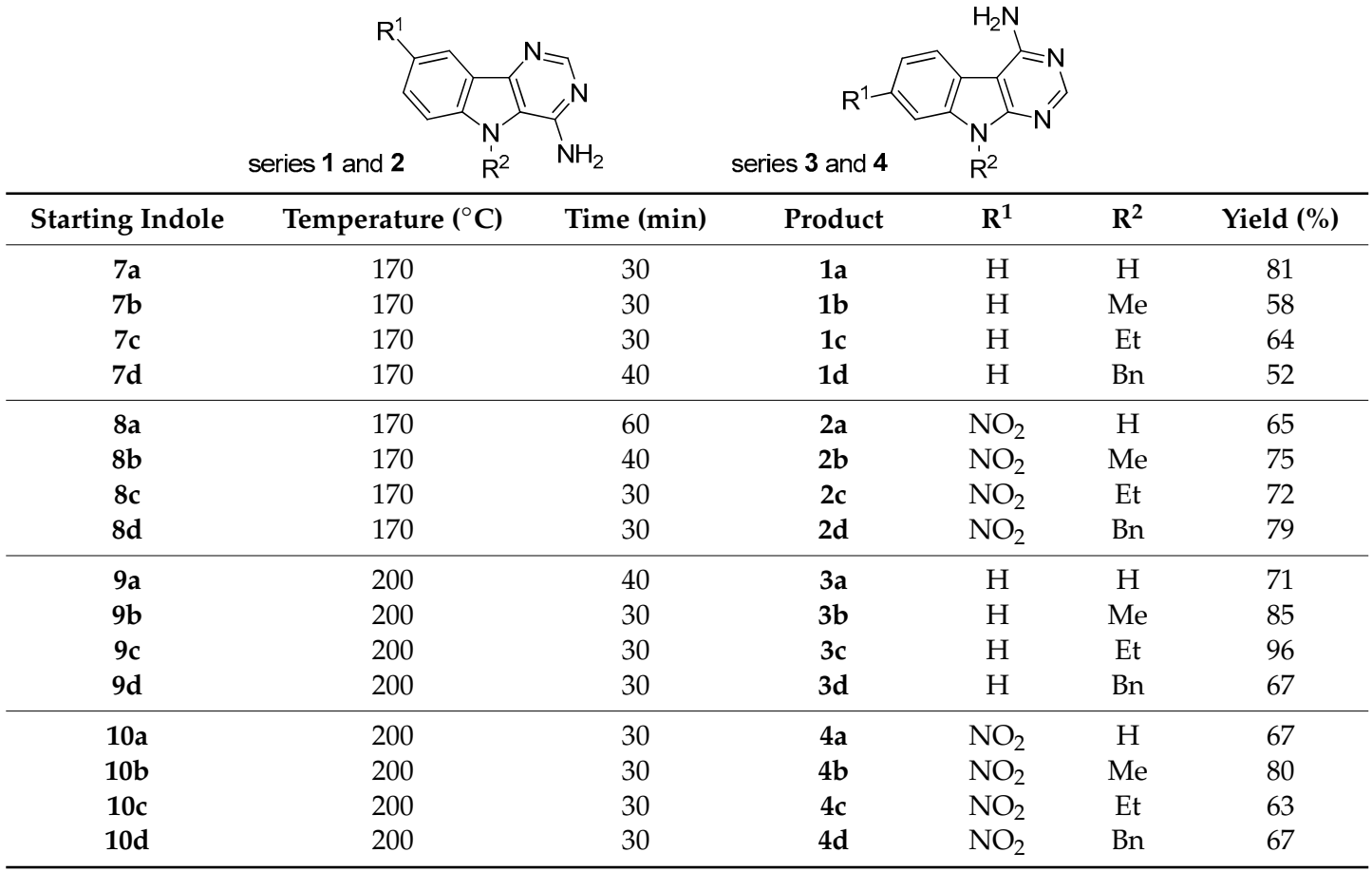<smiles>[R]c1ccc2[nH]c(C#N)c(N)c2c1</smiles>

$5 a$ and $5 b$



$60 \mathrm{~min}$

$(57-75 \%)$

Domino DMF-dialkylacetal mediated formylation $+N$-alkylation<smiles>[R1]c1ccc2c(c1)c(N=CN(C)C)c(C#N)n2[R]</smiles>

7 and 8

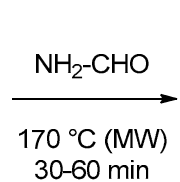

( $52-81 \%)$

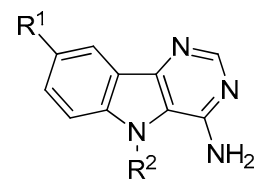

1 and 2

$$
\begin{aligned}
& 7 \text { and } 9 ; R^{1}=H \\
& 8 \text { and } 10 ; R^{1}=\mathrm{NO}_{2} \\
& R^{2}=H, M e, E t \text { or } B n
\end{aligned}
$$

Formamide-mediated cyclization<smiles>[R]c1ccc2c(C#N)c(N)n([2H])c2c1</smiles>

$6 a$ and $6 b$

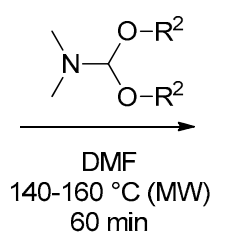

$(43-95 \%)$<smiles>[R]c1ccc2c(C#N)c(/N=C/N(C)C)n([R7])c2c1</smiles>

9 and 10

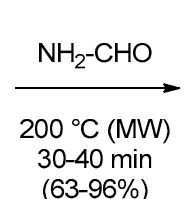

(63-96\%)<smiles>[R]c1ccc2c3c(N)ncnc3n([R])c2c1</smiles>

3 and 4

Scheme 1. Synthesis of $9 H$-pyrimido[5,4- $b$ ]indol-4-amines (series $\mathbf{1 a - d}$ and $\mathbf{2 a - d}$ ) and their $9 H$-pyrimido $[4,5-b]$ indoles isomers (series $\mathbf{3 a}-\mathbf{d}$ and $\mathbf{4 a} \mathbf{a}-\mathbf{d}$ ).

To compare the biological results of harmine (11a) and some of its N9-alkylated derivatives (11b-d) with the pyrimidoindoles prepared in this work (series 1, 2, 3, and 4, Table 1), we decided to explore the capacity of DMF-dialkylacetals to transfer an alkyl group to nucleophilic atoms, as an interesting alternative to previous methods [27-30]. Then, harmine was heated under controlled microwave-assisted heating in sealed vials $(10 \mathrm{~mL})$ in the presence of 10 equiv. of DMF-DMA, DMF-DEA, or DMF-DBA. The corresponding N9-alkylated 7-methoxy-1-methyl- $\beta$-carbolines (11b-d) were obtained in good yields (Scheme 2, Table 2). 

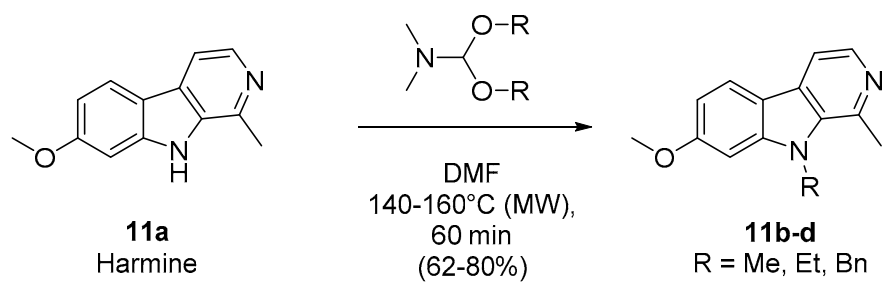

Scheme 2. Microwave-assisted synthesis of $N$-alkylated harmine derivatives (compounds $\mathbf{1 1} \mathbf{b}-\mathbf{d}$ ).

Table 2. Synthesis of compounds $\mathbf{1 1 b} \mathbf{- d}$ : experimental conditions and isolated yields.

\begin{tabular}{cccc}
\hline $\begin{array}{l}\boldsymbol{N}, \boldsymbol{N} \text {-dimethylformamide } \\
(\mathrm{DMF}) \text {-dialkylacetal (R) }\end{array}$ & Temperature $\left({ }^{\circ} \mathrm{C}\right)$ & Product & Yield (\%) \\
\hline DMF-DMA (Me) & 140 & $\mathbf{1 1 b}$ & 79 \\
DMF-DEA (Et) & 160 & $\mathbf{1 1 c}$ & 80 \\
DMF-DBA (Bn) & 160 & $\mathbf{1 1 d}$ & 62 \\
\hline
\end{tabular}

\subsection{Biological Evaluation}

The inhibitory potency of the synthesized pyrimido[4,5- $b$ ]indol-4-amines and pyrimido[5,4- $b$ ] indol-4-amines towards CDK5/p25, CK1 / $/ \varepsilon$, DYRK1A, and GSK-3 $\alpha / \beta$ was investigated according preceding procedures [11-14]. Data are listed in Table 3 including results obtained with harmine (11a) and its congeners $(\mathbf{1 1} \mathbf{b}-\mathbf{d})$.

Table 3. Kinase inhibitory potencies $\left(\mathrm{IC}_{50}\right.$ in $\left.\mu \mathrm{M}\right){ }^{1}$ for compounds of the series $1,2,3$, and 4 .
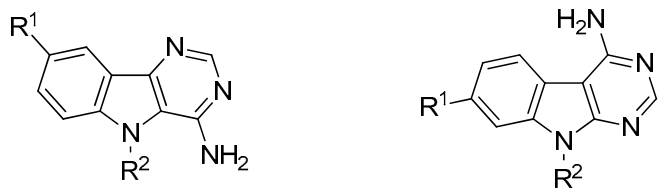<smiles>[R]n1c2cc(OC)ccc2c2ccnc(C)c21</smiles>

series 1 and 2

series 3 and $\mathbf{4}$

series 11

\begin{tabular}{|c|c|c|c|c|c|c|}
\hline Compound & $\mathbf{R}^{1}$ & $\mathbf{R}^{2}$ & CDK5/p25 & 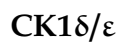 & DYRK1A & GSK-3 $\alpha / \beta$ \\
\hline $1 a$ & $\mathrm{H}$ & $\mathrm{H}$ & $>10$ & 2.0 & 2.2 & $>10$ \\
\hline $1 b$ & $\mathrm{H}$ & $\mathrm{Me}$ & $>10$ & 4.0 & 5.8 & $>10$ \\
\hline 1c & $\mathrm{H}$ & $\mathrm{Et}$ & $>10$ & 2.8 & 4.1 & $>10$ \\
\hline $1 d$ & $\mathrm{H}$ & $\mathrm{Bn}$ & $>10$ & 0.6 & $>10$ & $>10$ \\
\hline $2 a$ & $\mathrm{NO}_{2}$ & $\mathrm{H}$ & $>10$ & $>10$ & 7.6 & $>10$ \\
\hline $2 b$ & $\mathrm{NO}_{2}$ & $\mathrm{Me}$ & $>10$ & $>10$ & $>10$ & $>10$ \\
\hline $2 c$ & $\mathrm{NO}_{2}$ & Et & $>10$ & $>10$ & $>10$ & $>10$ \\
\hline $2 d$ & $\mathrm{NO}_{2}$ & $\mathrm{Bn}$ & $>10$ & $>10$ & $>10$ & $>10$ \\
\hline $3 a$ & $\mathrm{H}$ & $\mathrm{H}$ & 6 & 0.7 & 3.1 & $>10$ \\
\hline $3 b$ & $\mathrm{H}$ & $\mathrm{Me}$ & $>10$ & 2.5 & $>10$ & $>10$ \\
\hline $3 c$ & $\mathrm{H}$ & $\mathrm{Et}$ & $>10$ & 1.6 & 9.8 & $>10$ \\
\hline $3 d$ & $\mathrm{H}$ & $\mathrm{Bn}$ & $>10$ & 2.7 & $>10$ & $>10$ \\
\hline $4 a$ & $\mathrm{NO}_{2}$ & $\mathrm{H}$ & $>10$ & 3.5 & 7.6 & $>10$ \\
\hline $4 b$ & $\mathrm{NO}_{2}$ & $\mathrm{Me}$ & $>10$ & 2.8 & $>10$ & $>10$ \\
\hline $4 c$ & $\mathrm{NO}_{2}$ & Et & $>10$ & 1.6 & 5.9 & $>10$ \\
\hline $4 d$ & $\mathrm{NO}_{2}$ & $\mathrm{Bn}$ & $>10$ & $>10$ & $>10$ & $>10$ \\
\hline 11a (Harmine) & \multicolumn{2}{|c|}{$\mathrm{R}=\mathrm{H}$} & $>10$ & 1.5 & 0.029 & $>10$ \\
\hline $11 b$ & \multicolumn{2}{|c|}{$\mathrm{R}=\mathrm{Me}$} & $>10$ & $>10$ & 0.13 & $>10$ \\
\hline 11c & \multicolumn{2}{|c|}{$\mathrm{R}=\mathrm{Et}$} & $>10$ & $>10$ & 0.037 & $>10$ \\
\hline 11d & \multicolumn{2}{|c|}{$\mathrm{R}=\mathrm{Bn}$} & $>10$ & $>10$ & 0.059 & $>10$ \\
\hline
\end{tabular}

${ }^{1}$ Average of triplicate determination ( $<10 \%$ variation among values). 
All the tested compounds were inactive against CDK-5/p25 and GSK3 $\alpha / \beta$. 8-Nitro-5H-pyrimido [5,4- $b$ ]indol-4-amines (2a-d) were also inactive against the two other tested kinases, except compound 2a which exhibited a micromolar range $\mathrm{IC}_{50}$ value $(7.6 \mu \mathrm{M})$ against DYRK1A. General comparison of series 1, 3 , and 4 revealed a similar inhibitory activity against the array of four kinases. Values were mainly in the micromolar range against CK1 $1 \delta / \varepsilon$, except compounds $1 \mathbf{d}$ and $3 \mathbf{a}$ which disclosed submicromolar $\mathrm{IC}_{50}$ values $(0.6$ and $0.7 \mu \mathrm{M}$, respectively). It can be noted that $1 \mathbf{d}$ seemed more specific for $\mathrm{CK} 1 \delta / \varepsilon$ in view of its lack of activity against DYRK1A, whilst 3a maintained a micromolar affinity $\left(\mathrm{IC}_{50}=3.1 \mu \mathrm{M}\right)$ against this biological target.

Considering $\mathrm{CK} 1 \delta / \varepsilon$ kinase inhibition, the introduction of a nitro group was deleterious for series 1 vs. series $\mathbf{2}$, whereas inhibitory activity remained for series 3 vs. series $\mathbf{4}$, depending of the orientation of the aminopyrimidine ring in the fused system and its relative position to the nitro group. On the other hand, for the unsubstituted tricyclic derivatives on indole (series $\mathbf{1}$ and $\mathbf{3}$ ) the position of the amino group does not seem critical since micromolar CK1 inhibition was conserved within the two series.

Interestingly, a loss of DYRK1A inhibitory activity was observed for the compounds bearing a $\mathrm{N}$-methyl or a $\mathrm{N}$-benzyl chain compared to their $\mathrm{NH}$ or $\mathrm{N}$-ethyl analogues, except for the inactive series 2 and the very active compounds $\mathbf{1 1 a}-\mathbf{d}$.

Tested as a positive control under the same conditions as series 1-4, harmine (11a) was definitely inactive against CDK5/p25 and GSK3 $\alpha / \beta$. This natural product shows interesting activity against DYRK1A and a weak inhibition of $\mathrm{CK} 1 \delta / \varepsilon\left(\mathrm{IC}_{50}=1.5 \mu \mathrm{M}\right)$ as previously mentioned in various papers relating the use of harmine for treatment of neurodegenerative diseases [31,32]. The $N$-methyl, $N$-ethyl, and $N$-benzyl derivatives $(\mathbf{1 1 b}, \mathbf{1 1 c}$, and 11d) were totally inactive against the three kinases CDK5/p25, CK1 $\delta / \varepsilon$, and GSK3 $\alpha / \beta$. Their affinity was focused on DYRK1A with interesting $\mathrm{IC}_{50}$ values, quite close to the nanomolar range $\mathrm{IC}_{50}$ obtained for the lead harmine (11a) (see Table 3), confirming recently-published results [29].

\section{Discussion}

Results described above confirm the interest in developing chemical methods that allow easy access to libraries of various potentially bioactive molecules. This is particularly noticeable in the case of compounds $\mathbf{1 a}$ and $\mathbf{1 b}$, which are the only derivatives of these new series that were already synthesized via multistep processes (2-4 steps), in long time reactions (6-20 h) and sometimes difficult operating conditions, using toxic reagents (e.g., $\mathrm{POCl}_{3}$ ) [33]. The combination of microwave-assisted heating and the use of DMF-dialkylacetals provided in all cases short reaction times and comfortable operating conditions.

The two unsubstituted isomeric forms (series $\mathbf{1 a}-\mathbf{d}$ and $\mathbf{3 a} \mathbf{a}-\mathbf{d}$ ) expressed a similar average activity against the two kinases CK1 $/ \varepsilon$ and DYRK1A. Moreover, the data obtained for the two series of pyrimidoindoles bearing a nitro group, demonstrate that the pyrimido[4,5- $b$ ]indol-4-amines (series $\mathbf{4 a - d )}$ are more active than their pyrimido[5,4- $b$ ]indol-4-amine isomers (series $\mathbf{2} \mathbf{a}-\mathbf{d}$ ). In case of the first series (1a-d and $\mathbf{2 a}-\mathbf{d}$ ), the data suggest that addition of a nitro group significantly decreases the inhibitory activity. In contrast, the two sets of pyrimido[4,5- $b$ ]indol-4-amines (3a-d and $4 \mathbf{a}-\mathbf{d})$ exhibit similar micromolar range $\mathrm{IC}_{50}$ values which are independent of the substitution pattern on the benzene moiety of the indole ring.

Figure 2 focuses on the two kinases mainly inhibited in this study and the $\mathrm{IC}_{50}$ values towards CK1 $\delta / \varepsilon$ and DYRK1A protein kinases are reported for selected pyrimido[4,5- $b$ or 5,4- $b$ ]indol-4-amines (1a, 2a, 3a, and 4a). Inhibitory activity is compared with the biological data already published for thieno[2,3- $d$ ]pyrimidin-4-amine analogues described as potential Ser/Thr kinases inhibitors [12-14]. 


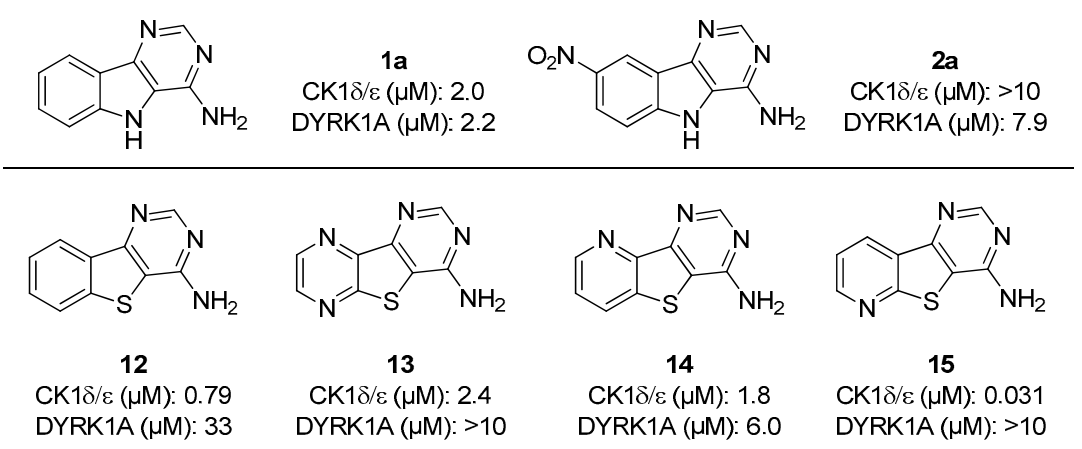

Figure 2. Comparison between selected pyrimido[4,5- $b$ or 5,4- $b]$ indol-4-amines described in this work and some of their thieno[2,3- $d$ ]pyrimidin-4-amine congeners $(12,13,14$ and 15) described in preceding work.

It can be observed that the replacement of the sulfur atom, in the structure of compound 12, by a nitrogen atom $(\mathrm{NH}$, more exactly, in compound 1a) resulted in increasing DYRK1A inhibitory potency (from 33 to $2.2 \mu \mathrm{M}$ ) and keeping CK1 activity. The major difference between the two compounds lies in the nature of the hydrogen bonding (acceptor for $\mathrm{S}$ vs. donor for $\mathrm{NH}$ ) that would allow a particular binding mode and interaction with the target protein, explaining this trend. When comparing the activity of nitroindole derivative $2 \mathrm{a}$ with the deactivated analogues 13,14 , and 15 , due to the presence of a pyrazine or a pyridine ring, opposite selectivity towards CK1 $/ \varepsilon$ and DYRK1A was observed. Indeed, the last ones displayed micromolar and submicromolar activity against $\mathrm{CK} 1$ and no activity on DYRK1A, whereas compound $2 \mathbf{a}$ exhibited no inhibition against CK1 $\delta / \varepsilon$ and low micromolar activity towards DYRK1A. Again, the four compounds behave identically in terms of electronic deficiency but, for three of them, we assumed that the presence of a nitrogen atom could bring an additional possibility of interaction with the protein through the lone pair of electrons.

\section{Materials and Methods}

\subsection{General Information}

All reagents were purchased from commercial suppliers and were used without further purification, except for DMF, which was stored under argon and activated molecular sieves. All reactions were monitored by thin-layer chromatography with silica gel 60 F254 (Merck KGaA, Darmstadt, Germany) precoated aluminium plates $(0.25 \mathrm{~mm})$. Visualization was performed with a UV light at wavelengths of $254 \mathrm{~nm}$. Purifications were conducted with a flash column chromatography system equipped with a dual UV/vis spectrophotometer (200-600 nm), a fraction collector (176 tubes), a dual piston pump ( 1 to $200 \mathrm{~mL} / \mathrm{min}$, Pmax = 15 bar), which allowed quaternary gradients, and an additional inlet for air purge ((Puriflash, Interchim, Montluçon, France). Melting points of solid compounds were measured with a SMP3 melting point instrument (STUART, Bibby Scientific Ltd., Roissy, France) with a precision of $1.5{ }^{\circ} \mathrm{C}$. IR spectra were recorded with a Spectrum 100 Series FTIR spectrometer (PerkinElmer, Villebon S/Yvette, France). NMR spectra $\left({ }^{1} \mathrm{H}\right.$ and ${ }^{13} \mathrm{C}$ ) were acquired at $295 \mathrm{~K}$ using an AVANCE $300 \mathrm{MHz}$ spectrometer (Bruker, Wissembourg, France) at 300 and $75.4 \mathrm{MHz}$, using trimethylsilane (TMS) as an internal standard. Coupling constants $J$ are in $\mathrm{Hz}$, and chemical shifts are given in ppm. Mass spectrometry was performed by the Mass Spectrometry Laboratory of the University of Rouen. The mass spectra electrospray ionization (ESI), electron impact ionization (EI), and field desorption (FD) were recorded with an LCP 1er XR spectrometer (WATERS, Guyancourt, France). Microwave experiments were carried out at atmospheric pressure in 50-250 $\mathrm{mL}$ round bottom flasks fitted with a reflux condenser, in a RotoSYNTH ${ }^{\mathrm{TM}}$ (Milestone S.r.l., Milano, Italy), a multi-mode cavity microwave reactor designed for synthetic chemistry $(0-1200 \mathrm{~W})$. Microwave reactions in sealed tubes $(10 \mathrm{~mL})$ were performed with a Initiator ${ }^{\mathrm{TM}}$ microwave synthesis instrument (Biotage, Uppsala, Sweden) $(0-400 \mathrm{~W})$. Temperatures of the reactions were monitored via IR-sensors. The percentage of 
purity of all tested products was more than $95 \%$ determined by high pressure liquid chromatography (HPLC) analysis. ${ }^{1} \mathrm{H}-\mathrm{NMR}$ and ${ }^{13} \mathrm{C}-\mathrm{NMR}$ spectra of new compounds are available in Supplementary Materials Section Figures S1-S16.

\subsection{Chemistry}

All details conerning the synthesis of $N^{\prime}$-(3-Cyano-1-alkyl-1H-indol-2-yl)- $N, N$-dimethylformimidamide intermediates (7a-d, $\mathbf{8 a}-\mathbf{d}, \mathbf{9 a}-\mathbf{d}$, and $\mathbf{1 0 a - d})$ are described in a preceding work [26].

Compounds $1 \mathbf{a}$ and $\mathbf{1 b}$ were already described and data given in the corresponding patent are only ${ }^{1} \mathrm{H}$ NMR spectra [33]. Harmine derivatives $\mathbf{1 1 b}$, 11c, and 11d were described in a preceding work [28] cited in some recent studies [29,30].

4.2.1. General Procedure for the Synthesis of 5H-Pyrimido[5,4-b]indol-4-amines (Series 1 and 2) and 5 H-Pyrimido[4,5-b]indol-4-amines (Series 3 and 4).

Formamide (40 equiv.) was added to the formimidamide precursor ( $7 \mathbf{b}-\mathbf{d}, \mathbf{8 b}-\mathbf{d}, \mathbf{9 b}-\mathbf{d}$, or $\mathbf{1 0 b}-\mathbf{d})$ $(1 \mathrm{mmol})$ and the mixture was heated under microwave irradiation $(200 \mathrm{~W})$. On completion, the reaction was cooled to room temperature and water was added. The solid was filtered off, washed with water, and dried. The crude solid was purified by silica gel column chromatography using PE/EtOAc (100:0 to $0: 100, v / v)$ as the eluent to give the desired compounds.

5H-Pyrimido[5,4-b]indol-4-amine (1a): brown powder $(0.149 \mathrm{~g}, 81 \%)$ obtained from $7 \mathbf{a}$ after $30 \mathrm{~min}$ of irradiation at $170{ }^{\circ} \mathrm{C}$ according to the general procedure; $\mathrm{mp}>320^{\circ} \mathrm{C}$; IR (neat) $v_{\max }\left(\mathrm{cm}^{-1}\right): 3047$, 1616, 1600, 1559, 1498, 1462, 1428, 1354, 1343, 1316, 1295, 1234, 1207, 1119, 756, 745; ${ }^{1} \mathrm{H}$ NMR (300 MHz, DMSO- $d_{6}$ ): $\delta 10.98$ (br s, $\left.1 \mathrm{H}, \underline{N} \underline{H}\right), 8.29(\mathrm{~s}, 1 \mathrm{H}, \underline{H}-2), 8.05(\mathrm{~d}, 1 \mathrm{H}, J=8 \mathrm{~Hz}, \underline{H}-8), 7.63(\mathrm{~d}, 1 \mathrm{H}, J=8 \mathrm{~Hz}$, $\underline{H}-6), 7.50\left(\mathrm{td}, 1 \mathrm{H}, J_{1}=2 \mathrm{~Hz}, J_{2}=8 \mathrm{~Hz}, \underline{H}-7\right), 7.22\left(\mathrm{td}, 1 \mathrm{H}, J_{1}=2 \mathrm{~Hz}, J_{2}=8 \mathrm{~Hz}, \underline{H}-6\right), 6.95\left(\mathrm{~s}, 2 \mathrm{H}, \mathrm{N}_{2}\right)$; ${ }^{13} \mathrm{C}$ NMR $\left(75 \mathrm{MHz}\right.$, DMSO- $\left.d_{6}\right): \delta 150.8,149.9,141.9,138.8,127.7,120.9,120.4,119.5,117.4,112.5 ;$ HRMS calcd for $\mathrm{C}_{10} \mathrm{H}_{9} \mathrm{~N}_{4}[\mathrm{M}+\mathrm{H}]^{+} 185.0827$ found 185.0822

5-Methyl-5H-pyrimido[5,4-b]indol-4-amine (1b): brown powder $(0.115 \mathrm{~g}, 58 \%)$ obtained from $7 \mathbf{b}$ after $30 \mathrm{~min}$ of irradiation at $170{ }^{\circ} \mathrm{C}$ according to the general procedure; $\mathrm{mp}$ 201-202 ${ }^{\circ} \mathrm{C}$; IR (neat) $\gamma_{\max }\left(\mathrm{cm}^{-1}\right): 3074,1657,1623,1590,1537,1493,1462,1431,1400,1352,1329,1244,962,842,789,737 ;{ }^{1} \mathrm{H}$ NMR (300 MHz, DMSO- $\left.d_{6}\right): \delta 8.29$ (s, $\left.1 \mathrm{H}, \underline{H}-2\right), 8.06(\mathrm{~d}, 1 \mathrm{H}, J=8 \mathrm{~Hz}, \underline{H}-9), 7.69(\mathrm{~d}, 1 \mathrm{H}, J=8 \mathrm{~Hz}, \underline{H}-6)$, $7.58\left(\mathrm{td}, 1 \mathrm{H}, J_{1}=2 \mathrm{~Hz}, J_{2}=8 \mathrm{~Hz}, \underline{H}-7\right), 7.24\left(\mathrm{td}, 1 \mathrm{H}, J_{1}=2 \mathrm{~Hz}, J_{2}=8 \mathrm{~Hz}, \underline{H}-8\right), 6.93\left(\mathrm{~s}, 2 \mathrm{H}, \mathrm{N}_{2}\right), 4.08(\mathrm{~s}$, $\left.3 \mathrm{H}, \mathrm{C}_{3}\right) ;{ }^{13} \mathrm{C}$ NMR $\left(75 \mathrm{MHz}, \mathrm{DMSO}-d_{6}\right): \delta 151.4,149.7,140.9,128.0,120.4,120.3,119.5,114.2,110.4$, 106.3, 31.7; HRMS calcd for $\mathrm{C}_{11} \mathrm{H}_{11} \mathrm{~N}_{4}[\mathrm{M}+\mathrm{H}]^{+} 199.0984$ found 199.0981 .

5-Ethyl-5H-pyrimido[5,4-b]indol-4-amine (1c): brown powder $(0.136 \mathrm{~g}, 64 \%)$ obtained from $7 \mathrm{c}$ after $30 \mathrm{~min}$ of irradiation at $170{ }^{\circ} \mathrm{C}$ according to the general procedure; $\mathrm{mp} 161-162{ }^{\circ} \mathrm{C}$; IR (neat) $v_{\max }\left(\mathrm{cm}^{-1}\right)$ : $3349,1641,1589,1532,1402,1382,1334,1226,1046,1024,988,827,729 ;{ }^{1} \mathrm{H}$ NMR (300 MHz, DMSO- $\left.d_{6}\right)$ : $\delta 8.31(\mathrm{~s}, 1 \mathrm{H}, \underline{H}-2), 8.08(\mathrm{~d}, 1 \mathrm{H}, J=8 \mathrm{~Hz}, \underline{H}-9), 7.72(\mathrm{~d}, 1 \mathrm{H}, J=8 \mathrm{~Hz}, \underline{H}-6), 7.58\left(\mathrm{td}, 1 \mathrm{H}, J_{1}=2 \mathrm{~Hz}, J_{2}=8\right.$ $\mathrm{Hz}, \underline{H}-7), 7.22\left(\mathrm{td}, 1 \mathrm{H}, J_{1}=2 \mathrm{~Hz}, J_{2}=8 \mathrm{~Hz}, \underline{H}-8\right), 6.90\left(\mathrm{~s}, 2 \mathrm{H}, \mathrm{N}_{2}\right), 4.61\left(\mathrm{q}, 2 \mathrm{H}, J=7 \mathrm{~Hz}, \mathrm{C}_{2}\right), 1.21(\mathrm{t}$, $\left.3 \mathrm{H}, J=7 \mathrm{~Hz}, \mathrm{CH}_{3}\right) ;{ }^{13} \mathrm{C}$ NMR $\left(75 \mathrm{MHz}, \mathrm{DMSO}-d_{6}\right): \delta 150.9,149.7,140.1,128.1,120.7,120.5,119.6,118.2$, 112.1, 110.4, 39.7, 16.0; HRMS calcd for $\mathrm{C}_{12} \mathrm{H}_{13} \mathrm{~N}_{4}[\mathrm{M}+\mathrm{H}]^{+} 213.1140$ found 213.1133.

5-Benzyl-5H-pyrimido[5,4-b]indol-4-amine (1d): yellow powder $(0.143 \mathrm{~g}, 52 \%)$ obtained from $7 \mathbf{d}$ after $40 \mathrm{~min}$ of irradiation at $170{ }^{\circ} \mathrm{C}$ according to the general procedure; $\mathrm{mp} 219-220^{\circ} \mathrm{C}$; IR (neat) $v_{\max }\left(\mathrm{cm}^{-1}\right): 3062,1641,1619,1581,1530,1494,1453,1403,1378,1330,1254,1207,1193,954,754,734$; ${ }^{1} \mathrm{H}$ NMR (300 MHz, DMSO- $\left.d_{6}\right): \delta 8.33(\mathrm{~s}, 1 \mathrm{H}, \underline{H}-2), 8.10(\mathrm{~d}, 1 \mathrm{H}, J=8 \mathrm{~Hz}, \underline{H}-9), 7.79(\mathrm{~d}, 1 \mathrm{H}, J=8 \mathrm{~Hz}$, $\underline{H}-6), 7.55\left(\mathrm{td}, 1 \mathrm{H}, J_{1}=2 \mathrm{~Hz}, J_{2}=8 \mathrm{~Hz}, \underline{H}-7\right), 7.28-7.17\left(\mathrm{~m}, 4 \mathrm{H}, \underline{H}-8\right.$, and $\underline{H}$-ar), $7.00\left(\mathrm{dd}, 2 \mathrm{H}, J_{1}=1 \mathrm{~Hz}\right.$, $\left.J_{2}=8 \mathrm{~Hz}, \underline{H}-\mathrm{ar}\right), 6.90\left(\mathrm{~s}, 2 \mathrm{H}, \mathrm{N}_{2}\right), 5.87\left(\mathrm{~s}, 2 \mathrm{H}, \mathrm{C}_{2}\right) ;{ }^{13} \mathrm{C} \mathrm{NMR}\left(75 \mathrm{MHz}, \mathrm{DMSO}-d_{6}\right): \delta 151.0,150.0$, 143.8, 141.0, 138.3, 128.5 (2C), 128.3, 127.2, 126.2 (2C), 120.9, 120.5, 120.0, 118.0, 111.1, 46.9; HRMS calcd for $\mathrm{C}_{17} \mathrm{H}_{15} \mathrm{~N}_{4}[\mathrm{M}+\mathrm{H}]^{+} 275.1297$ found 275.1295 .

8-Nitro-5H-pyrimido[5,4-b]indol-4-amine (2a): brown powder $(0.149 \mathrm{~g}, 65 \%)$ obtained from $8 \mathbf{a}$ after $60 \mathrm{~min}$ of irradiation at $170{ }^{\circ} \mathrm{C}$ according to the general procedure; $\mathrm{mp}>320^{\circ} \mathrm{C}$; IR (neat) $v_{\max }\left(\mathrm{cm}^{-1}\right)$ : $3102,1692,1627,1597,1548,1512,1474,1453,1377,1321,1303,1233,1131,1044,816,733 ;{ }^{1}$ H NMR 
(300 MHz, DMSO- $\left.d_{6}\right): \delta 11.73$ (br s, $\left.1 \mathrm{H}, \mathrm{N} \underline{H}\right), 8.89(\mathrm{~d}, 1 \mathrm{H}, J=1 \mathrm{~Hz}, \underline{H}-9), 8.40(\mathrm{~s}, 1 \mathrm{H}, \underline{H}-2), 8.35$ (dd, $1 \mathrm{H}$, $\left.J_{1}=1 \mathrm{~Hz}, J_{2}=8 \mathrm{~Hz}, \underline{H}-7\right), 7.85(\mathrm{~d}, 1 \mathrm{H}, J=8 \mathrm{~Hz}, \underline{H}-6), 7.22\left(\mathrm{~s}, 2 \mathrm{H}, \mathrm{N}_{2}\right) ;{ }^{13} \mathrm{C}$ NMR $\left(75 \mathrm{MHz}\right.$, DMSO- $\left.d_{6}\right):$ $\delta 151.4,151.3,142.6,141.4,140.5,122.5,120.4,119.4,117.2,113.3$; HRMS calcd for $\mathrm{C}_{10} \mathrm{H}_{8} \mathrm{~N}_{5} \mathrm{O}_{2}[\mathrm{M}+\mathrm{H}]^{+}$ 230.0678 found 230.0682 .

5-Methyl-8-nitro-5H-pyrimido[5,4-b]indol-4-amine (2b): yellow powder $(0.182 \mathrm{~g}, 75 \%)$ obtained from $8 \mathbf{b}$ after $40 \mathrm{~min}$ of irradiation at $170{ }^{\circ} \mathrm{C}$ according to the general procedure; $\mathrm{mp}>320{ }^{\circ} \mathrm{C}$; IR (neat) $\gamma_{\max }\left(\mathrm{cm}^{-1}\right): 3087,1617,1585,1510,1472,1327,1302,1259,1235,1083,1026,915,844,791,729 ;{ }^{1} \mathrm{H}$ NMR (300 MHz, DMSO- $\left.d_{6}\right): \delta 8.89(\mathrm{~d}, 1 \mathrm{H}, J=1 \mathrm{~Hz}, \underline{H}-9), 8.40\left(\mathrm{dd}, 1 \mathrm{H}, J_{1}=1 \mathrm{~Hz}, J_{2}=8 \mathrm{~Hz}, \underline{H}-7\right)$, $8.39(\mathrm{~s}, 1 \mathrm{H}, \underline{H}-2), 7.90(\mathrm{~d}, 1 \mathrm{H}, J=8 \mathrm{~Hz}, \underline{H}-6), 7.21\left(\mathrm{~s}, 2 \mathrm{H}, \mathrm{N}_{2}\right), 4.14\left(\mathrm{~s}, 3 \mathrm{H}, \mathrm{CH}_{3}\right) ;{ }^{13} \mathrm{C}$ NMR $(75 \mathrm{MHz}$, DMSO- $\left.d_{6}\right): \bar{\delta} 151.9,151.1,143.5,143.0,140.3,122.7,120.5,119.7,117.1,111.3,32.4$; HRMS calcd for $\mathrm{C}_{11} \mathrm{H}_{10} \mathrm{~N}_{5} \mathrm{O}_{2}[\mathrm{M}+\mathrm{H}]^{+} 244.0834$ found 244.0827 .

5-Ethyl-8-nitro-5H-pyrimido[5,4-b]indol-4-amine (2c): yellow powder (0.185 g, 72\%) obtained from $8 \mathrm{c}$ after $30 \mathrm{~min}$ of irradiation at $170{ }^{\circ} \mathrm{C}$ according to the general procedure; $\mathrm{mp} 299-300{ }^{\circ} \mathrm{C}$; IR (neat) $v_{\max }\left(\mathrm{cm}^{-1}\right): 3072,1617,1586,1507,1475,1456,1329,1302,1257,1227,1090,944,805,753,735 ;{ }^{1} \mathrm{H}$ NMR $\left(300 \mathrm{MHz}, \mathrm{DMSO}-d_{6}\right): \delta 8.91(\mathrm{~d}, 1 \mathrm{H}, J=1 \mathrm{~Hz}, \underline{H}-9), 8.42(\mathrm{~s}, 1 \mathrm{H}, \underline{H}-2), 8.40\left(\mathrm{dd}, 1 \mathrm{H}, J_{1}=1 \mathrm{~Hz}, J_{2}=8 \mathrm{~Hz}\right.$, $\underline{H}-7), 7.97(\mathrm{~d}, 1 \mathrm{H}, J=8 \mathrm{~Hz}, \underline{H}-6), 7.23\left(\mathrm{~s}, 2 \mathrm{H}, \overline{\mathrm{N}} \underline{H}_{2}\right), 4.70\left(\mathrm{q}, 2 \mathrm{H}, J=7 \mathrm{~Hz}, \underline{C}_{2}\right), 1.27(\mathrm{t}, 3 \mathrm{H}, J=7 \mathrm{~Hz}$, $\left.\overline{\mathrm{C}}_{3}\right) ;{ }^{13} \mathrm{C}$ NMR $\left(75 \mathrm{MHz}, \mathrm{DMSO}-d_{6}\right): \delta 152.4,152.3,144.1,142.3,140.5,122.9,120.1,119.3,117.2,111.3$, 40.1, 16.1; HRMS calcd for $\mathrm{C}_{12} \mathrm{H}_{12} \mathrm{~N}_{5} \mathrm{O}_{2}[\mathrm{M}+\mathrm{H}]^{+} 258.0991$ found 258.0986 .

5-Benzyl-8-nitro-5H-pyrimido[5,4-b]indol-4-amine (2d): yellow powder $(0.252 \mathrm{~g}, 79 \%)$ obtained from $8 \mathbf{d}$ after $30 \mathrm{~min}$ of irradiation at $170{ }^{\circ} \mathrm{C}$ according to the general procedure; $\mathrm{mp}>320^{\circ} \mathrm{C}$; IR (neat) $v_{\max }\left(\mathrm{cm}^{-1}\right): 3052,1643,1620,1586,1513,1473,1451,1400,1331,1315,1203,1076,1045,939,804,791$, 732; ${ }^{1} \mathrm{H}$ NMR $\left(300 \mathrm{MHz}\right.$, DMSO- $\left.d_{6}\right): \delta 8.94(\mathrm{~d}, 1 \mathrm{H}, J=1 \mathrm{~Hz}, \underline{H}-9), 8.44(\mathrm{~s}, 1 \mathrm{H}, \underline{H}-2), 8.41(\mathrm{dd}, 1 \mathrm{H}$, $\left.J_{1}=1 \mathrm{~Hz}, J_{2}=8 \mathrm{~Hz}, \underline{H}-7\right), 8.03(\mathrm{~d}, 1 \mathrm{H}, J=8 \mathrm{~Hz}, \underline{H}-6), 7.28-7.18\left(\mathrm{~m}, 5 \mathrm{H}, \underline{\mathrm{H}}_{2}\right.$, and $\left.\underline{H}-\mathrm{ar}\right), 7.01$ (dd, $\left.2 \mathrm{H}, J_{1}=1 \mathrm{~Hz}, J_{2}=8 \mathrm{~Hz}, \underline{H}-\mathrm{ar}\right), 5.99\left(\mathrm{~s}, 2 \mathrm{H}, \underline{\mathrm{C}}_{2}\right) ;{ }^{13} \mathrm{C}$ NMR $\left(75 \mathrm{MHz}, \mathrm{DMSO}-d_{6}\right): \delta 151.5(2 \mathrm{C}), 144.3$, 143.3, 140.9, 137.4, 128.7 (2C), 127.5, 126.1 (2C), 123.2, 120.4, 119.7, 117.2, 111.9, 47.4; HRMS calcd for $\mathrm{C}_{17} \mathrm{H}_{14} \mathrm{~N}_{5} \mathrm{O}_{2}[\mathrm{M}+\mathrm{H}]^{+} 320.1147$ found 320.1145 .

9H-Pyrimido[4,5-b]indol-4-amine (3a): cream-coloured powder $(0.131 \mathrm{~g}, 71 \%)$ obtained from $N^{\prime}$-(3-cyano- $1 H$-indol-2-yl)- $N, N$-dimethylformimidamide 9 a after $40 \mathrm{~min}$ of irradiation at $200{ }^{\circ} \mathrm{C}$ according to the general procedure; $\mathrm{mp}>320^{\circ} \mathrm{C}$; IR (neat) $v_{\max }\left(\mathrm{cm}^{-1}\right): 3068,1637,1624,1604,1580$, $1569,1302,1255,981,798,750,705 ;{ }^{1} \mathrm{H}$ NMR $\left(300 \mathrm{MHz}, \mathrm{DMSO}-d_{6}\right): \delta 11.81$ (br s, $\left.1 \mathrm{H}, \mathrm{N} \underline{H}\right), 8.27(\mathrm{~d}, 1 \mathrm{H}$, $J=8 \mathrm{~Hz}, \underline{H}-5), 8.24(\mathrm{~s}, 1 \mathrm{H}, \underline{H}-2), 7.43(\mathrm{~d}, 1 \mathrm{H}, J=8 \mathrm{~Hz}, \underline{H}-8), 7.34\left(\mathrm{td}, 1 \mathrm{H}, J_{1}=1 \mathrm{~Hz}, J_{2}=8 \mathrm{~Hz}, \underline{H}-7\right), 7.22$ $\left(\mathrm{td}, 1 \mathrm{H}, J_{1}=1 \mathrm{~Hz}, J_{2}=8 \mathrm{~Hz}, \underline{H}-6\right), 7.13\left(\mathrm{~s}, 2 \mathrm{H}, \underline{N}_{2}\right) ;{ }^{13} \mathrm{C}$ NMR $\left(75 \mathrm{MHz}, \mathrm{DMSO}-d_{6}\right): \delta 157.6,155.6,154.8$, 136.2, 124.4, 121.2, 120.0, 119.8, 110.8, 95.2; HRMS calcd for $\mathrm{C}_{10} \mathrm{H}_{9} \mathrm{~N}_{4}[\mathrm{M}+\mathrm{H}]^{+} 185.0827$ found 185.0820.

9-Methyl-9H-pyrimido[4,5-b]indol-4-amine (3b): brown powder $(0.168 \mathrm{~g}, 85 \%)$ obtained from $\mathbf{9 b}$ after $30 \mathrm{~min}$ of irradiation at $200{ }^{\circ} \mathrm{C}$ according to the general procedure; mp 189-190 ${ }^{\circ} \mathrm{C}$; IR (neat) $v_{\max }\left(\mathrm{cm}^{-1}\right): 3059,1622,1588,1556,1507,1463,1449,1326,1309,1300,1194,978,795,731 ;{ }^{1} \mathrm{H}$ NMR (300 MHz, DMSO- $\left.d_{6}\right): \delta 8.32(\mathrm{~d}, 1 \mathrm{H}, J=8 \mathrm{~Hz}, \underline{H}-5), 8.31(\mathrm{~s}, 1 \mathrm{H}, \underline{H}-2), 7.59(\mathrm{~d}, 1 \mathrm{H}, J=8 \mathrm{~Hz}, \underline{H}-8), 7.43(\mathrm{td}$, $\left.1 \mathrm{H}, J_{1}=1 \mathrm{~Hz}, J_{2}=8 \mathrm{~Hz}, \underline{H}-7\right), 7.29\left(\mathrm{td}, 1 \mathrm{H}, J_{1}=1 \mathrm{~Hz}, J_{2}=8 \mathrm{~Hz}, \underline{H}-6\right), 7.22\left(\mathrm{~s}, 2 \mathrm{H}, \underline{N}_{2}\right), 3.82(\mathrm{~s}, 3 \mathrm{H}$, $\left.\mathrm{C}_{3}\right) ;{ }^{13} \mathrm{C}$ NMR $\left(75 \mathrm{MHz}, \mathrm{DMSO}-d_{6}\right): \delta 157.7,155.2,154.9,137.5,124.7,124.4,121.2,120.3,119.3,109.2$, 28.1; HRMS calcd for $\mathrm{C}_{11} \mathrm{H}_{11} \mathrm{~N}_{4}[\mathrm{M}+\mathrm{H}]^{+} 199.0984$ found 199.0974 .

9-Ethyl-9H-pyrimido[4,5-b]indol-4-amine (3c): brown powder (0.204 g, 96\%) obtained from 9c after 30 min of irradiation at $200{ }^{\circ} \mathrm{C}$ according to the general procedure; mp $137-138^{\circ} \mathrm{C}$; IR (neat) $v_{\max }\left(\mathrm{cm}^{-1}\right)$ : $3062,1623,1558,1448,1464,1329,1113,798,736,708 ;{ }^{1} \mathrm{H}$ NMR $\left(300 \mathrm{MHz}\right.$, DMSO-d $\left.d_{6}\right): \delta 8.34(\mathrm{~d}, 1 \mathrm{H}$, $J=8 \mathrm{~Hz}, \underline{H}-5), 8.32(\mathrm{~s}, 1 \mathrm{H}, \underline{H}-2), 7.63(\mathrm{~d}, 1 \mathrm{H}, J=8 \mathrm{~Hz}, \underline{H}-8), 7.45\left(\mathrm{td}, 1 \mathrm{H}, J_{1}=1 \mathrm{~Hz}, J_{2}=8 \mathrm{~Hz}, \underline{H}-7\right), 7.26$ $\left(\mathrm{td}, 1 \mathrm{H}, J_{1}=1 \mathrm{~Hz}, J_{2}=8 \mathrm{~Hz}, \underline{H}-6\right), 7.21\left(\mathrm{~s}, 2 \mathrm{H}, \mathrm{N}_{2}\right), 4.41\left(\mathrm{q}, 2 \mathrm{H}, J=7 \mathrm{~Hz}, \underline{C}_{2}\right), 1.31(\mathrm{t}, 3 \mathrm{H}, J=7 \mathrm{~Hz}$, $\left.\mathrm{C}_{3}\right) ;{ }^{13} \mathrm{C}$ NMR $\left(75 \mathrm{MHz}, \mathrm{DMSO}-d_{6}\right): \delta 157.5,154.8,154.5,136.3,124.5,121.4,120.3,119.6,109.3,94.8$, 35.7, 14.0; HRMS calcd for $\mathrm{C}_{12} \mathrm{H}_{13} \mathrm{~N}_{4}[\mathrm{M}+\mathrm{H}]^{+} 213.1140$ found 213.1130 .

9-Benzyl-9H-pyrimido[4,5-b]indol-4-amine (3d): cream-coloured powder (0.184 g, 67\%) obtained from $9 \mathrm{~d}$ after $30 \mathrm{~min}$ of irradiation at $200{ }^{\circ} \mathrm{C}$ according to the general procedure; mp 217-218 ${ }^{\circ} \mathrm{C}$; IR (neat) $\gamma_{\max }\left(\mathrm{cm}^{-1}\right): 3051,1620,1585,1568,1556,1458,1445,1428,1297,799,753,740 ;{ }^{1} \mathrm{H} \mathrm{NMR}$ 
(300 MHz, DMSO- $\left.d_{6}\right): \delta 8.34(\mathrm{~d}, 1 \mathrm{H}, J=8 \mathrm{~Hz}, \underline{H}-5), 8.33(\mathrm{~s}, 1 \mathrm{H}, \underline{H}-2), 7.55(\mathrm{~d}, 1 \mathrm{H}, J=8 \mathrm{~Hz}, \underline{H}-8), 7.37$ $\left(\mathrm{td}, 1 \mathrm{H}, J_{1}=1 \mathrm{~Hz}, J_{2}=8 \mathrm{~Hz}, \underline{H}-7\right), 7.29-7.21\left(\mathrm{~m}, 8 \mathrm{H}, \underline{H}-6, \mathrm{~N}_{2}\right.$, and $\left.\underline{H}-\mathrm{ar}\right), 5.60\left(\mathrm{~s}, 2 \mathrm{H}, \mathrm{CH}_{2}\right) ;{ }^{13} \mathrm{C} \mathrm{NMR}$ (75 MHz, DMSO- $d_{6}$ ): $\delta$ 157.6, 155.0, 137.5, 136.6, 128.5 (2C), 127.3, 127.1 (2C), 124.6, 121.4, 120.6, 119.6, 117.2, 109.8, 94.8, 44.0; HRMS calcd for $\mathrm{C}_{17} \mathrm{H}_{15} \mathrm{~N}_{4}[\mathrm{M}+\mathrm{H}]^{+} 275.1297$ found 275.1292.

7-Nitro-9H-pyrimido[4,5-b]indol-4-amine (4a): brown powder $(0.153 \mathrm{~g}, 67 \%)$ obtained from 10a after $30 \mathrm{~min}$ of irradiation at $200^{\circ} \mathrm{C}$ according to the general procedure; $\mathrm{mp}>320^{\circ} \mathrm{C}$; IR (neat) $v_{\max }\left(\mathrm{cm}^{-1}\right)$ : $3052,1621,1529,1500,1471,1375,1304,1287,1257,1204,1124,1071,884,820,753,734 ;{ }^{1} \mathrm{H}$ NMR (300 MHz, DMSO-d $\left.d_{6}\right): \delta 12.42$ (br s, $\left.1 \mathrm{H}, \mathrm{N} \underline{H}\right), 8.53(\mathrm{~d}, 1 \mathrm{H}, J=9 \mathrm{~Hz}, \underline{H}-5), 8.34(\mathrm{~s}, 1 \mathrm{H}, \underline{H}-2), 8.25$ (d, $1 \mathrm{H}$, $J=2 \mathrm{~Hz}, \underline{H}-8), 8.11\left(\mathrm{dd}, 1 \mathrm{H}, J_{1}=2 \mathrm{~Hz}, J_{2}=9 \mathrm{~Hz}, \underline{H}-6\right), 7.62\left(\mathrm{~s}, 2 \mathrm{H}, \mathrm{N}_{2}\right) ;{ }^{13} \mathrm{C}$ NMR $\left(75 \mathrm{MHz}, \mathrm{DMSO}-d_{6}\right)$ : $\delta 158.4,157.9,156.8,143.8,135.4,125.5,121.2,115.2,106.5,94.9 ;$ HRMS calcd for $\mathrm{C}_{10} \mathrm{H}_{8} \mathrm{~N}_{5} \mathrm{O}_{2}[\mathrm{M}+\mathrm{H}]^{+}$ 230.0678 found 230.0689 .

9-Methyl-7-nitro-9H-pyrimido[4,5-b]indol-4-amine (4b): yellow powder $(0.195 \mathrm{~g}, 80 \%)$ obtained from $10 \mathrm{~b}$ after $30 \mathrm{~min}$ of irradiation at $200{ }^{\circ} \mathrm{C}$ according to the general procedure $\mathrm{G} ; \mathrm{mp} 309-310{ }^{\circ} \mathrm{C}$; IR (neat) $v_{\max }\left(\mathrm{cm}^{-1}\right): 3031,1568,1513,1482,1331,1309,1284,1273,1193,987,875,853,811,726 ;{ }^{1} \mathrm{H}$ NMR $\left(300 \mathrm{MHz}, \mathrm{DMSO}-d_{6}\right): \delta 8.55(\mathrm{~d}, 1 \mathrm{H}, J=9 \mathrm{~Hz}, \underline{H}-5), 8.51(\mathrm{~d}, 1 \mathrm{H}, J=2 \mathrm{~Hz}, \underline{H}-8), 8.39(\mathrm{~s}, 1 \mathrm{H}, \underline{H}-2), 8.12$ $\left(\mathrm{dd}, 1 \mathrm{H}, J_{1}=2 \mathrm{~Hz}, J_{2}=9 \mathrm{~Hz}, \underline{\mathrm{H}}-6\right), 7.67\left(\mathrm{~s}, 2 \mathrm{H}, \underline{\mathrm{N}}_{2}\right), 3.91\left(\mathrm{~s}, 3 \mathrm{H}, \mathrm{C}_{3}\right) ;{ }^{13} \mathrm{C} \mathrm{N} M R\left(75 \mathrm{MHz}, \overline{D M S O}_{-} d_{6}\right):$ $\delta 158.2,157.3,156.7,144.0,136.7,124.9,121.1,115.5,105.5,94.5,27.9$; HRMS calcd for $\mathrm{C}_{11} \mathrm{H}_{10} \mathrm{~N}_{5} \mathrm{O}_{2}[\mathrm{M}+$ $\mathrm{H}^{+} 244.0834$ found 244.0831 .

9-Ethyl-7-nitro-9H-pyrimido[4,5-b]indol-4-amine (4c): brown powder $(0.162 \mathrm{~g}, 63 \%)$ obtained from 10c after $30 \mathrm{~min}$ of irradiation at $200^{\circ} \mathrm{C}$ according to the general procedure; $\mathrm{mp} 285-286^{\circ} \mathrm{C}$; IR (neat) $\gamma_{\max }\left(\mathrm{cm}^{-1}\right): 3109,1618,1582,1563,1509,1485,1448,1322,1276,1184,1135,820,743,732 ;{ }^{1} \mathrm{H}$ NMR (300 MHz, DMSO- $\left.d_{6}\right): \delta 8.58(\mathrm{~d}, 1 \mathrm{H}, J=2 \mathrm{~Hz}, \underline{H}-8), 8.55$ (d, $\left.1 \mathrm{H}, J=9 \mathrm{~Hz}, \underline{H}-5\right), 8.39$ (s, $\left.1 \mathrm{H}, \underline{H}-2\right), 8.12$ $\left(\mathrm{dd}, 1 \mathrm{H}, J_{1}=2 \mathrm{~Hz}, J_{2}=9 \mathrm{~Hz}, \underline{H}-6\right), 7.69\left(\mathrm{~s}, 2 \mathrm{H}, \underline{\mathrm{N}}_{2}\right), 4.53\left(\mathrm{q}, 2 \mathrm{H}, J=7 \mathrm{~Hz}, \underline{\mathrm{C}}_{2}\right), 1.32(\mathrm{t}, 3 \mathrm{H}, J=7 \mathrm{~Hz}$, $\left.\mathrm{C}_{3}\right) ;{ }^{13} \mathrm{C}$ NMR $\left(75 \mathrm{MHz}, \mathrm{DMSO}-d_{6}\right): \delta 158.3,156.8,156.7,144.1,135.6,125.1,121.3,115.4,105.4,94.5$, 36.2, 14.1; HRMS calcd for $\mathrm{C}_{12} \mathrm{H}_{12} \mathrm{~N}_{5} \mathrm{O}_{2}[\mathrm{M}+\mathrm{H}]^{+} 258.0991$ found 258.0999.

9-Benzyl-7-nitro-9H-pyrimido[4,5-b]indol-4-amine (4d): yellow powder $(0.214 \mathrm{~g}, 67 \%)$ obtained from $10 \mathrm{~d}$ after $30 \mathrm{~min}$ of irradiation at $200{ }^{\circ} \mathrm{C}$ according to the general procedure; $\mathrm{mp} 241-242{ }^{\circ} \mathrm{C}$; IR (neat) $v_{\max }\left(\mathrm{cm}^{-1}\right): 3031,1558,1508,1477,1448,1319,1268,1170,1086,801,733 ;{ }^{1} \mathrm{H}$ NMR $\left(300 \mathrm{MHz}, \mathrm{DMSO}-d_{6}\right)$ : $\delta 8.60(\mathrm{~d}, 1 \mathrm{H}, J=2 \mathrm{~Hz}, \underline{H}-8), 8.49(\mathrm{~d}, 1 \mathrm{H}, J=9 \mathrm{~Hz}, \underline{H}-5), 8.43(\mathrm{~s}, 1 \mathrm{H}, \underline{H}-2), 8.13\left(\mathrm{dd}, 1 \mathrm{H}, J_{1}=2 \mathrm{~Hz}, J_{2}=9\right.$ $\mathrm{Hz}, \underline{H}-6), 7.76\left(\mathrm{~s}, 2 \mathrm{H}, \underline{\mathrm{N}}_{2}\right), 7.32-7.21(\mathrm{~m}, 5 \mathrm{H}, \underline{\mathrm{H}}-\mathrm{ar}), 4.53\left(\mathrm{~s}, 2 \mathrm{H}, \underline{\mathrm{C}}_{2}\right) ;{ }^{13} \mathrm{C}$ NMR $\left(75 \mathrm{MHz}, \mathrm{DMSO}-d_{6}\right)$ :

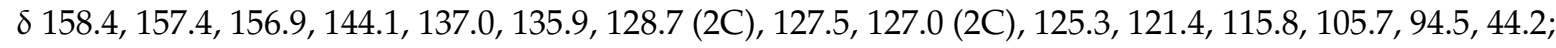
HRMS calcd for $\mathrm{C}_{17} \mathrm{H}_{14} \mathrm{~N}_{5} \mathrm{O}_{2}[\mathrm{M}+\mathrm{H}]^{+} 320.1147$ found 320.1133 .

4.2.2. General Procedure for the Synthesis of $N$-alkylated Harmine Derivatives (Compounds $\mathbf{1 1} \mathbf{b}-\mathbf{d}$ ).

A mixture of starting harmine (11a, $212 \mathrm{mg}, 1 \mathrm{mmol}$ ) and corresponding DMF-dialkylacetal (DMF-DMA, DMF-DEA, or DMF-DBA) $(10 \mathrm{mmol})$ in DMF $(10 \mathrm{mmol})$ was irradiated (atmospheric pressure) at various temperatures $(800 \mathrm{~W})$. On completion, the solution was cooled to room temperature and crude products were extracted with ethylacetate. The organic layers were washed with cold water, dried over $\mathrm{Na}_{2} \mathrm{SO}_{4}$, filtered, and evaporated in vacuo. Purification by silica gel column chromatography using a gradient of dichloromethane/ethylacetate (100:0 to 0:100, $v / v)$ as the eluent gave the desired products.

7-Methoxy-1,9-dimethyl- $\beta$-carboline (11b): Yield: 79\%, obtained from DMF-DMA after 60 min of irradiation at $140{ }^{\circ} \mathrm{C}$ according to the general procedure; $\mathrm{mp} 125-126{ }^{\circ} \mathrm{C} ;{ }^{1} \mathrm{H}$ NMR (300 MHz, DMSO- $d_{6}$ ): $\delta 8.14(\mathrm{~d}, 1 \mathrm{H}, J=5 \mathrm{~Hz}, \underline{H}-3), 8.09$ (d, $1 \mathrm{H}, J=8 \mathrm{~Hz}, \underline{H}-5), 7.86(\mathrm{~d}, 1 \mathrm{H}, J=5 \mathrm{~Hz}, \underline{H}-4), 7.20(\mathrm{~d}, 1 \mathrm{H}, J=2 \mathrm{~Hz}$, $\underline{H}-8), 6.86\left(\mathrm{dd}, 1 \mathrm{H}, J_{1}=2 \mathrm{~Hz}, J_{2}=8 \mathrm{~Hz}, \underline{H}-6\right), 4.13\left(\mathrm{~s}, 3 \mathrm{H}, \mathrm{NC}_{H_{3}}\right), 3.92\left(\mathrm{~s}, 3 \mathrm{H}, \mathrm{OC} \underline{H}_{3}\right), 3.01\left(\mathrm{~s}, 3 \mathrm{H}, \underline{\mathrm{C}}_{3}\right)$; HRMS calcd for $\mathrm{C}_{14} \mathrm{H}_{15} \mathrm{~N}_{2} \mathrm{O}[\mathrm{M}+\mathrm{H}]^{+} 227.1184$ found 227.1180 .

9-Ethyl-7-methoxy-1-methyl- $\beta$-carboline (11c): Yield: 80\%, obtained from DMF-DEA after $60 \mathrm{~min}$ of irradiation at $160{ }^{\circ} \mathrm{C}$ according to the general procedure; mp $109-110{ }^{\circ} \mathrm{C} ;{ }^{1} \mathrm{H} \mathrm{NMR}(300 \mathrm{MHz}$, DMSO- $\left.d_{6}\right): \delta 8.16(\mathrm{~d}, 1 \mathrm{H}, J=5 \mathrm{~Hz}, \underline{H}-3), 8.09(\mathrm{~d}, 1 \mathrm{H}, J=8 \mathrm{~Hz}, \underline{H}-5), 7.87(\mathrm{~d}, 1 \mathrm{H}, J=5 \mathrm{~Hz}, \underline{H}-4), 7.20$ $(\mathrm{d}, 1 \mathrm{H}, J=2 \mathrm{~Hz}, \underline{H}-8), 6.87\left(\mathrm{dd}, 1 \mathrm{H}, J_{1}=2 \mathrm{~Hz}, J_{2}=8 \mathrm{~Hz}, \underline{H}-6\right), 4.62\left(\mathrm{q}, 2 \mathrm{H}, J=7 \mathrm{~Hz}, \underline{C}_{2}\right), 3.92(\mathrm{~s}$, 
$\left.3 \mathrm{H}, \mathrm{OCH}_{3}\right), 2.96\left(\mathrm{~s}, 3 \mathrm{H}, \mathrm{CH}_{3}\right), 1.35\left(\mathrm{t}, 3 \mathrm{H}, \mathrm{J}=7 \mathrm{~Hz}, \mathrm{CH}_{2} \underline{\mathrm{CH}}_{3}\right)$; HRMS calcd for $\mathrm{C}_{15} \mathrm{H}_{17} \mathrm{~N}_{2} \mathrm{O}[\mathrm{M}+\mathrm{H}]^{+}$ 241.1341 found 241.1338.

9-Benzyl-7-methoxy-1-methyl- $\beta$-carboline (11d): Yield: 62\%, obtained from DMF-DBA after $60 \mathrm{~min}$ of irradiation at $160{ }^{\circ} \mathrm{C}$ according to the general procedure; mp $131-132{ }^{\circ} \mathrm{C} ;{ }^{1} \mathrm{H}$ NMR $(300 \mathrm{MHz}$, DMSO- $\left.d_{6}\right): \delta 8.18(\mathrm{~d}, 1 \mathrm{H}, J=5 \mathrm{~Hz}, \underline{H}-3), 8.14(\mathrm{~d}, 1 \mathrm{H}, J=8 \mathrm{~Hz}, \underline{H}-5), 7.94(\mathrm{~d}, 1 \mathrm{H}, J=5 \mathrm{~Hz}, \underline{H}-4), 7.38-7.19$ (m, 5H, $\underline{H}-8$, and $\underline{H}$-ar), 6.94-6.89 (m, $2 \mathrm{H}, \underline{H}-6$, and $\underline{H}$-ar), $5.90\left(\mathrm{~s}, 2 \mathrm{H}, \underline{\mathrm{C}}_{2}\right), 3.82$ (s, 3H, $\left.\mathrm{OC}_{3}\right), 2.74$ (s, $\left.3 \mathrm{H}, \mathrm{CH}_{3}\right)$; HRMS calcd for $\mathrm{C}_{20} \mathrm{H}_{19} \mathrm{~N}_{2} \mathrm{O}[\mathrm{M}+\mathrm{H}]^{+} 303.1497$ found 303.1499 .

\subsection{In Vitro Kinase Preparation and Assays}

Buffers, kinase preparations, and assays were performed as described in ref. [12-14] according methods initially published in previous works [34-36].

Supplementary Materials: The following materials are available online at http://www.mdpi.com/1424-8247/13/5/ 89/s1. Figures S1-S16. 1H- \& 13C-NMR Spectra for Compounds 1a-d, 2a-d, 3a-d and 4a-d.

Author Contributions: P.M. and T.B. conceived the project and designed the experiments; Y.L. performed the experimental work, accompanied by C.D.-B. and M.-R.N.; L.M. designed and supervised the overall aspect of biological experiments; N.L. ran the kinase assays; and P.M. wrote the manuscript with the cooperation of T.B. All authors discussed the results and commented on the manuscript. All authors have read and agreed to the published version of the manuscript.

Funding: T.B. and his co-workers (Y.L. and C.D.-B.) thank the LABEX SynOrg (ANR-11-LABX-0029) for financial support. L.M. was supported by the Fondation J. Lejeune.

Acknowledgments: Financial support from the MESR (Ministère de l'Enseignement Supérieur \& de la Recherche) is gratefully acknowledged for the doctoral fellowships to Y.L. T.B. and his co-workers thank the University of Rouen-Normandie for its support.

Conflicts of Interest: The authors declare no conflict of interest. The founding sponsors had no role in the design of the study; in the collection, analyses, or interpretation of data; in the writing of the manuscript, or in the decision to publish the results.

\section{References}

1. Manning, G.; Whyte, D.B.; Martinez, R.; Hunter, T.; Sudarsanam, S. The Protein Kinase Complement of the Human Genome. Science 2002, 298, 1912-1934. [CrossRef] [PubMed]

2. Ionescu, A.; Dufrasne, F.; Gelbcke, M.; Jabin, I.; Kiss, R.; Lamoral-Theys, D. DYRK1A kinase inhibitors with emphasis on cancer. Mini Rev. Med. Chem. 2012, 12, 1315-1329. [CrossRef] [PubMed]

3. Fernández-Martínez, P.; Zahonero, C.; Sánchez-Gómez, P. DYRK1A: The double-edged kinase as a protagonist in cell growth and tumorigenesis. Mol. Cell. Oncol. 2015, 2, 970048. [CrossRef] [PubMed]

4. Duchon, A.; Herault, Y. DYRK1A, a Dosage-Sensitive Gene Involved in Neurodevelopmental Disorders, Is a Target for Drug Development in Down Syndrome. Front. Behav. Neurosci. 2016, 10, 87. [CrossRef] [PubMed]

5. Branca, C.; Shaw, D.M.; Belfiore, R.; Gokhale, V.; Shaw, A.Y.; Foley, C.; Smith, B.; Hulme, C.; Dunckley, T.; Meechoovet, B.; et al. Dyrk1 inhibition improves Alzheimer's disease-like pathology. Aging Cell 2017, 16, 1146-1154. [CrossRef] [PubMed]

6. Stotani, S.; Giordanetto, F.; Medda, F. DYRK1A inhibition as potential treatment for Alzheimer's disease. Future Med. Chem. 2016, 8, 681-696. [CrossRef]

7. Roskoski, R. Properties of FDA-approved small molecule protein kinase inhibitors: A 2020 update. Pharmacol. Res. 2020, 152, 104609. [CrossRef]

8. Alexandre, F.-R.; Berecibar, A.; Wrigglesworth, R.; Besson, T. Efficient synthesis of thiazoloquinazolinone derivatives. Tetrahedron Lett. 2003, 44, 4455-4458. [CrossRef]

9. Loidreau, Y.; Besson, T. Microwave-assisted thermal decomposition of formamide: A tool for coupling a pyrimidine ring with an aromatic partner. Tetrahedron 2011, 67, 4852-4857. [CrossRef]

10. Foucourt, A.; Dubouilh-Benard, C.; Chosson, E.; Corbiere, C.; Buquet, C.; Iannelli, M.; Leblond, B.; Marsais, F.; Besson, T. Microwave-accelerated Dimroth rearrangement for the synthesis of 4-anilino-6-nitroquinazolines. Application to an efficient synthesis of a microtubule destabilizing agent. Tetrahedron 2010, 66, 4495-4502. [CrossRef] 
11. Loidreau, Y.; Dubouilh-Benard, C.; Marchand, P.; Nourrisson, M.-R.; Duflos, M.; Buquet, C.; Corbière, C.; Besson, T. Efficient New Synthesis ofN-Arylbenzo [b] furo [3,2-d] pyrimidin-4-amines and Their Benzo [b] thieno [3,2-d] pyrimidin-4-amine Analogues via a Microwave-Assisted Dimroth Rearrangement. J. Heterocycl. Chem. 2013, 50, 1187-1197. [CrossRef]

12. Loidreau, Y.; Marchand, P.; Dubouilh-Benard, C.; Nourrisson, M.-R.; Duflos, M.; Loaëc, N.; Meijer, L.; Besson, T. Synthesis and biological evaluation of N-aryl-7-methoxybenzo [b] furo [3,2-d] pyrimidin-4-amines and their N-arylbenzo [b] thieno [3,2-d] pyrimidin-4-amine analogues as dual inhibitors of CLK1 and DYRK1A kinases. Eur. J. Med. Chem. 2013, 59, 283-295. [CrossRef] [PubMed]

13. Loidreau, Y.; Marchand, P.; Dubouilh-Benard, C.; Nourrisson, M.-R.; Duflos, M.; Lozach, O.; Loaëc, N.; Meijer, L.; Besson, T. Synthesis and biological evaluation of $\mathrm{N}$-arylbenzo[b]thieno[3,2-d]pyrimidin-4-amines and their pyrido and pyrazino analogues as Ser/Thr kinase inhibitors. Eur. J. Med. Chem. 2012, 58, 171-183. [CrossRef]

14. Loidreau, Y.; Deau, E.; Marchand, P.; Nourrisson, M.-R.; Logé, C.; Coadou, G.; Loaëc, N.; Meijer, L.; Besson, T. Synthesis and molecular modelling studies of 8-arylpyrido[ $\left.3^{\prime}, 2^{\prime}: 4,5\right]$ thieno[3,2-d]pyrimidin-4-amines as multitarget Ser/Thr kinases inhibitors. Eur. J. Med. Chem. 2015, 92, 124-134. [CrossRef]

15. Jarhad, D.B.; Mashelkar, K.K.; Kim, H.-R.; Noh, M.; Jeong, L.S. Dual-Specificity Tyrosine Phosphorylation-Regulated Kinase 1A (DYRK1A) Inhibitors as Potential Therapeutics. J. Med. Chem. 2018, 61, 9791-9810. [CrossRef]

16. Czarna, A.; Wang, J.; Zelencova, D.; Liu, Y.; Deng, X.; Choi, H.G.; Zhang, T.; Zhou, W.; Chang, J.W.; Kildalsen, H.; et al. Novel Scaffolds for Dual Specificity Tyrosine-Phosphorylation-Regulated Kinase (DYRK1A) Inhibitors. J. Med. Chem. 2018, 61, 7560-7572. [CrossRef] [PubMed]

17. Meijer, L.; Flajolet, M.; Greengard, P. Pharmacological inhibitors of glycogen synthase kinase 3. Trends Pharmacol. Sci. 2004, 25, 471-480. [CrossRef]

18. Ryoo, S.-R.; Jeong, H.K.; Radnaabazar, C.; Yoo, J.-J.; Cho, H.-J.; Lee, H.-W.; Kim, I.-S.; Cheon, Y.-H.; Ahn, Y.S.; Chung, S.-H.; et al. DYRK1A-mediated Hyperphosphorylation of Tau. J. Boil. Chem. 2007, 282, 34850-34857. [CrossRef] [PubMed]

19. Vasquez, A.A.; Aulchenko, Y.S.; Isaacs, A.; Van Oosterhout, A.; Sleegers, K.; Hofman, A.; Van Broeckhoven, C.; Oostra, B.A.; Breteler, M.; Van Duijn, C.M. Cyclin-dependent kinase 5 is associated with risk for Alzheimer's disease in a Dutch population-based study. J. Neurol. 2008, 255, 655-662. [CrossRef]

20. Cozza, G.; Pinna, L.A. Casein kinases as potential therapeutic targets. Expert Opin. Ther. Targets 2015, 20, 319-340. [CrossRef]

21. Li, G.; Yin, H.; Kuret, J. Casein Kinase 1 Delta Phosphorylates Tau and Disrupts Its Binding to Microtubules. J. Boil. Chem. 2004, 279, 15938-15945. [CrossRef] [PubMed]

22. Smith, B.; Medda, F.; Gokhale, V.; Dunckley, T.; Hulme, C. Recent Advances in the Design, Synthesis, and Biological Evaluation of Selective DYRK1A Inhibitors: A New Avenue for a Disease Modifying Treatment of Alzheimer's? ACS Chem. Neurosci. 2012, 3, 857-872. [CrossRef] [PubMed]

23. Becker, W.; Joost, H.-G. Structural and functional characteristics of Dyrk, a novel subfamily of protein kinases with dual specificity. Prog. Nucleic Acid Res. Mol. Biol. 1999, 62, 1-17. [CrossRef] [PubMed]

24. Aranda, S.; Laguna, A.; De La Luna, S. DYRK family of protein kinases: Evolutionary relationships, biochemical properties, and functional roles. FASEB J. 2010, 25, 449-462. [CrossRef]

25. Tahtouh, T.; Elkins, J.M.; Filippakopoulos, P.; Soundararajan, M.; Burgy, G.; Durieu, E.; Cochet, C.; Schmid, R.; Lo, N.C.; Delhommel, F.; et al. Selectivity, Cocrystal Structures, and Neuroprotective Properties of Leucettines, a Family of Protein Kinase Inhibitors Derived from the Marine Sponge Alkaloid Leucettamine, B. J. Med. Chem. 2012, 55, 9312-9330. [CrossRef]

26. Loidreau, Y.; Melissen, S.; Levacher, V.; Logé, C.; Graton, J.; Le Questel, J.-Y.; Besson, T. Study of N1-alkylation of indoles from the reaction of 2 (or 3) -aminoindole-3- (or 2) carbonitriles with DMF-dialkylacetals. Org. Biomol. Chem. 2012, 10, 4916. [CrossRef]

27. Cao, R.; Fan, W.; Guo, L.; Ma, Q.; Zhang, G.; Li, J.; Chen, X.; Ren, Z.; Qiu, L. Synthesis and structure-activity relationships of harmine derivatives as potential antitumor agents. Eur. J. Med. Chem. 2013, 60, 135-143. [CrossRef]

28. Cao, R.; Chen, Q.; Hou, X.; Chen, H.; Guan, H.; Ma, Y.; Peng, W.; Xu, A. Synthesis, acute toxicities, and antitumor effects of novel 9-substituted $\beta$-carboline derivatives. Bioorg. Med. Chem. 2004, 12, 4613-4623. [CrossRef] 
29. Balint, B.; Weber, C.; Cruzalegui, F.; Burbridge, M.; Kotschy, A. Structure-based design and synthesis of Harmine derivatives with different selectivity profiles in kinase vs monoamine oxidase inhibition. Chem. Med. Chem. 2017, 12, 932-939. [CrossRef]

30. Du, H.; Tian, S.; Chen, J.; Gu, H.; Li, N.; Wang, J. Synthesis and biological evaluation of N9-substituted harmine derivatives as potential anticancer agents. Bioorg. Med. Chem. Lett. 2016, 26, 4015-4019. [CrossRef]

31. Patel, K.; Gadewar, M.; Tripathi, R.; Prasad, S.; Patel, D.K. A review on medicinal importance, pharmacological activity and bioanalytical aspects of beta-carboline alkaloid "Harmine". Asian Pac. J. Trop. Biomed. 2012, 2, 660-664. [CrossRef]

32. Adayev, T.; Wegiel, J.; Hwang, Y.-W. Harmine is an ATP-competitive inhibitor for dual-specificity tyrosine phosphorylation-regulated kinase 1A (Dyrk1A). Arch. Biochem. Biophys. 2010, 507, 212-218. [CrossRef] [PubMed]

33. Baell, J.B.; Street, I.P.; Sleebs, B.E. Pyrido [3',2':4,5] Thieno [3,2-d] Pyrimidin-4-Ylamine Derivatives and Their Therapeutical Use. Patent WO 2012/131297A1, 4 October 2012.

34. Primot, A.; Baratte, B.; Gompel, M.; Borgne, A.; Liabeuf, S.; Romette, J.-L.; Jho, E.-H.; Costantini, F.; Meijer, L. Purification of GSK-3 by Affinity Chromatography on Immobilized Axin. Protein Expr. Purif. 2000, 20, 394-404. [CrossRef] [PubMed]

35. Bach, S.; Knockaert, M.; Reinhardt, J.; Lozach, O.; Schmitt, S.; Baratte, B.; Koken, M.; Coburn, S.P.; Tang, L.; Jiang, T.; et al. Roscovitine Targets, Protein Kinases and Pyridoxal Kinase. J. Boil. Chem. 2005, 280, 31208-31219. [CrossRef]

36. Reinhardt, J.; Ferandin, Y.; Meijer, L. Purification of CK1 by affinity chromatography on immobilised axin. Protein Expr. Purif. 2007, 54, 101-109. [CrossRef] [PubMed]

(C) 2020 by the authors. Licensee MDPI, Basel, Switzerland. This article is an open access article distributed under the terms and conditions of the Creative Commons Attribution (CC BY) license (http://creativecommons.org/licenses/by/4.0/). 